\title{
Novel Experimental Cements for Use on the Dentin-Pulp Complex
}

\author{
Raquel Venâncio Fernandes DANTAS \\ Marcus Cristian Muniz CONDE \\ Hugo Ramalho SARMENTO \\ Cesar Henrique ZANCHI \\ Sandra Beatriz Chaves TARQUINIO \\ Fabrício Aulo OGLIARI \\ Flávio Fernando DEMARCO
}

Graduate Program in Dentistry, UFPel - Federal University of Pelotas, Pelotas, RS, Brazil

\begin{abstract}
This aim of this study was to evaluate the physicochemical and biological properties of novel experimental cements (Hybrid, Paste and Resin) based on synergistic combinations of existing materials, including $\mathrm{pH}$, diametral tensile strength (DTS) and cytotoxicity comparing them with mineral trioxide aggregate (MTA - Angelus ${ }^{\circledR}$ ) and a glass ionomer cement (GIC) developed at our laboratory. For the physicochemical and biological tests, specimens with standard dimensions were produced. $\mathrm{pH}$ measurements were performed with digital $\mathrm{pH}$ meter at the following time intervals: 3, 24, 48 and $72 \mathrm{~h}$. For the DTS test, cylindrical specimens were subjected to compressive load until fracture. The MTT assay was performed for cytotoxicity evaluation. Data were analyzed by ANOVA and Tukey's test $(\alpha=0.05)$. Paste group showed $\mathrm{pH}$ values similar to MTA, and Hybrid group presented $\mathrm{pH}$ values similar to GIC ( $\mathrm{p}>0.05$ ). The tested materials showed $\mathrm{pH}$ values ranging from alkaline to near neutrality at the evaluated times. MTA and GIC showed similar DTS values. The lowest and highest DTS values were seen in the Paste and Resin groups, respectively $(\mathrm{p}<0.05)$. Cell viability for MTA and experimental Hybrid, Paste and Resin groups was 49\%, 93\%, 90\% and 86\%, respectively, when compared with the control group. The photo-cured experimental resin cement showed similar or superior performance compared with the current commercial or other tested experimental materials.
\end{abstract}

Key Words: dental pulp, dental cements, pulp capping, biocompatibility, mechanical properties.

\section{INTRODUCTION}

Direct pulp capping relies on the application of a material directly on the exposed pulp to promote its vitality, while indirect pulp capping is conducted in teeth with deep carious lesions and presenting reversible pulp pathosis, when the protective material is placed over a remaining layer of dentin. Both treatments aim to maintain the vitality of pulp tissue and its biological homeostasis (1).

Several materials are commercially available for use as capping agents, and among them calcium hydroxide $(\mathrm{CH})$ has been one of the most widely used due to its ability to stimulate pulp repair and dentin bridge formation and its antimicrobial activity arising from the high $\mathrm{pH}$ generated by the material (2). However,
CH-based cements show several limitations, including high solubility, short-term effects, rapidly buffering by the fluid contents of dentinal tubules, low mechanical resistance and lack of adhesion to dental structures (3). In an attempt to improve the behavior of $\mathrm{CH}$-based cements, a light-cured material (Prisma VLC Dycal; Dentsply De Trey, Konstanz, Germany) was formulated using urethane dimethacrylate resin (UDMA), which improved the mechanical properties of chemically cured calcium hydroxide cements, while also enhancing their working times (2). However, a significant limitation of this photo-cured cement was the possible risk of pulpal injury from release of uncured monomers from the resin (4).

Mineral trioxide aggregate (MTA) has also found wide use as a pulp-capping agent (5). Other

Correspondence: Prof. Dr. Flávio Fernando Demarco, Faculdade de Odontologia, Universidade Federal de Pelotas, Rua Gonçalves Chaves 457, $5^{\circ}$ andar, 96015-568 Pelotas, RS, Brasil. Tel: +55-53-3222-6690. Fax +55-53-3225-6741. Ramal 135. e-mail: ffdemarco@gmail.com 
investigations have demonstrated improved mechanical and biological properties for MTA when compared with calcium hydroxide cements $(5,6)$. The superior biological responses of MTA have been attributed to the higher solubilization of growth factors from dentin with MTA, although other mechanisms may also contribute to its performance. Despite the promising results observed with this material, its handling characteristics and slow setting reaction are considered limitations of current MTA formulations (7).

Conventional glass ionomer cements (GICs) have been indicated for protection of the pulp-dentin complex, presenting valuable properties, such as fluoride release, coefficients of thermal expansion and elasticity modes similar to dentin, and adhesion to dental structures. However, some limitations are related to these materials, including their high solubility, relatively poor mechanical properties and long setting times (8). The addition of resinous compounds, such as 2-hydroxyethyl methacrylate (HEMA), to conventional GICs has improved their mechanical properties and resistance to wear (9), although accompanied by a reduction in biocompatibility due to release of uncured monomers causing pulpal irritation (4).

To improve the biocompatibility of resinous materials, new monomers have been proposed. Ethoxylated bisphenolA glycol dimethacrylate (BisEMA 30) has a high molecular weight, thereby reducing opportunities for monomer diffusion through dentin. Since the diffusion coefficient is inversely proportional to the molecular weight, the replacement of HEMA (MW=130 g/mol) by Bis-EMA 30 (MW=1,686 g/mol) should result in toxicity reduction (10).

While several materials have been indicated for capping procedures, there is still no ideal material that incorporates all the properties required for optimal performance. A combination of the properties of choice from the different current materials may allow an interesting approach to synergistically develop new dental cements with optimal properties, which could improve the outcomes of current pulp therapeutic strategies (11).

The purpose of this study was to develop new experimental dental cements for pulp capping, combining components of different currently available materials, including MTA. The tested hypothesis was that the experimental cements should exhibit better physicochemical and biological properties, when compared with commonly used current commercial materials (MTA and GIC).

\section{MATERIAL AND METHODS}

Experimental materials (hybrid, resinous, paste) based on MTA and GIC were developed and their compositions as well as those of the MTA (White MTA: Angelus, Londrina, PR, Brazil) and GIC used in the study are presented in Table 1.

\section{Post-Setting $\mathrm{pH}$ Changes}

For $\mathrm{pH}$ measurements, 15 standard disks $(\mathrm{h}=1$ $\mathrm{mm} ; \varnothing=6 \mathrm{~mm}$ ) were prepared for each material. They were either photoactivated by light-emitting diode source (LED - Radii-cal; SDI, São Paulo, SP, Brazil) with 1,200 $\mathrm{mW} / \mathrm{cm}^{2}$ light intensity for $40 \mathrm{~s}$ (dual-cure mode) or not photoactivated (self-curing mode). After preparation, the disks were placed in Eppendorf micro-tubes with $1 \mathrm{~mL}$ of culture medium (Dulbecco's Modified Eagle's Medium-DMEM, Sigma Chemical Co., St Louis, MO, USA) supplemented with $10 \%$ bovine fetal serum(FBS) (Cultilab, Campinas, SP, Brazil) and stored at $37^{\circ} \mathrm{C}$. The $\mathrm{pH}$ values were measured at the following intervals: 3 , 24, 48 and $72 \mathrm{~h}$ after preparation, using a digital $\mathrm{pH}$ meter (Quimis Q400A, Diadema, SP, Brazil). In the measurement intervals, the disks were carefully removed and placed in a new micro-tube with fresh medium (12).

\section{Diametral Tensile Strength (DTS) Test}

Standard disks $(\mathrm{h}=2 \pm 0.1 \mathrm{~mm} ; \varnothing=4 \pm 0.1 \mathrm{~mm})$ were prepared for each evaluated material $(n=8)$. The photocured materials were light-cured as described above. The borders were gently polished with 600 -grit abrasive paper (Norton Abrasivos Brasil, São Paulo, SP, Brazil) and the samples were stored at $37^{\circ} \mathrm{C}$ and $100 \%$ humidity for $24 \mathrm{~h}$ before the test. Then, the disks were measured with a digital caliper (Mitutoyo 500-144B;Suzano, SP, Brazil). The DTS test was performed in a universal testing machine (EMIC 2000; Equipamentos e Sistemas de Ensaio Ltda., São José dos Pinhais, PR, Brazil) under a $100 \mathrm{kgfload}$ at $0.5 \mathrm{~mm} / \mathrm{min}$. The resistance values were expressed in MPa.

\section{Cell Viability Evaluation}

An immortalized cell line, 3T3/NIH mouse fibroblasts, was grown in culture medium (Dulbecco's 
Modified Eagle's Medium - DMEM) supplemented with $10 \%$ fetal bovine serum and $1 \%$ antibiotics $(10,000 \mathrm{IU} /$ $\mathrm{mL}$ of penicillin $\mathrm{G}$ and $10,000 \mathrm{mg} / \mathrm{mL}$ of streptomycin; Gibco Laboratories Inc., Grand Island, NY, USA). The cells were seeded in culture dishes and maintained in an incubator $\left(37^{\circ} \mathrm{C}, 5 \%\right.$ of $\left.\mathrm{CO}_{2}\right)$ until getting subconfluent.

Standard disks $(\mathrm{h}=1 \mathrm{~mm}, \varnothing=4 \mathrm{~mm})$ were prepared for each material $(n=3)$ and individually placed in Eppendorf micro-tubes containing $1 \mathrm{~mL}$ of DMEM and maintained in an incubator $\left(37^{\circ} \mathrm{C}, 5 \%\right.$ of $\left.\mathrm{CO}_{2}\right)$ for $24 \mathrm{~h}$. The samples were then removed from the microtubes and the eluates from each material were added to 96 -well plates ( $\mathrm{n}=8$ per sample) where $2 \times 10^{4}$ cells were previously seeded. The $96-$ well plates were incubated $\left(37^{\circ} \mathrm{C}, 5 \%\right.$ of $\left.\mathrm{CO}_{2}\right)$ for $24 \mathrm{~h}$. Cell viability was assessed using the MTT assay. A control group was included containing only cells without addition of eluates.

Absorbance readings were measured using a universal ELISA reader (ELX 800; BIO-TEK Instruments, Winooski, VT, USA), with a $570 \mathrm{~nm}$ wavelength filter, where absorbance values were considered the indicator of cell viability. The inhibitory effect of the different tested materials on mitochondrial activity of cells was calculated and expressed as proportional rates compared with the control group.

\section{Statistical Analysis}

Statistical analyses were carried out using the SigmaStat ${ }^{\circledR}$ software package (Version 3.5 for Windows ${ }^{\circledR} ;$ Systat Software Corporation, San Jose, CA, USA) and analyzed descriptively. In addition, differences between groups were tested by ANOVA and Tukey's test with a significance level of $5 \%$.

\section{RESULTS}

\section{Post-Setting pH Change}

Changes in $\mathrm{pH}$ of the tested materials were observed along the various assessed time points (Table 2). The experimental Paste group showed changes in $\mathrm{pH}$ values similar to MTA for all the tested time intervals. The experimental Hybrid group exhibited a profile of $\mathrm{pH}$ change similar to the GIC ( $\mathrm{p}>0.05)$. After $72 \mathrm{~h}$, most materials showed a similar reduction in $\mathrm{pH}$ values, with the exception of the experimental resin group. This latter group showed significantly higher $\mathrm{pH}$ values after $72 \mathrm{~h}$ $(\mathrm{p}<0.05)$ compared with the other materials and its $\mathrm{pH}$ was relatively constant throughout the experiment. All the evaluated materials showed $\mathrm{pH}$ values ranging from

Table 1. Composition of experimental and commercial materials used in the study.

\begin{tabular}{|c|c|c|c|}
\hline Material & Composition & Curing mode & Proportion \\
\hline Hybrid & $\begin{array}{c}\text { Powder: GIC + MTA; } \\
\text { Liquid: distilled water and GIC liquid }\end{array}$ & Chemical & $1: 1$ \\
\hline Resinous & $\begin{array}{l}\text { Powder: MTA, yterbium fluoride, DHEPT, EDAB; } \\
\text { Liquid: PEGUDMA 400, TEGDMA, } \mathrm{H}_{2} \mathrm{O} \text {, GDMAP, } \\
\text { UDMA, camphorquinone, benzoylperoxide }\end{array}$ & Light activation & $3: 2$ \\
\hline Paste & $\begin{array}{l}\text { Paste 1: MTA, Bis-EMA 10, Bis-EMA 30, } \\
\text { camphorquinone, DHEPT, EDAB; } \\
\text { Paste 2: yterbium fluoride, Bis-EMA 10, } \\
\text { Bis-EMA 30, benzoyl peroxide }\end{array}$ & Light activation & $1: 1$ \\
\hline MTA (Angelus ${ }^{\circledR}$ ) & $\begin{array}{c}\text { Powder: } \mathrm{BI}_{2} \mathrm{O}_{3}, \mathrm{CaO}, \mathrm{MgO}, \mathrm{K}_{2} \mathrm{O}, \mathrm{Na}_{2} \mathrm{O} \\
\mathrm{Fe}_{2} \mathrm{O}_{3}, \mathrm{SO}_{3}, \mathrm{SiO}_{2}, \mathrm{Al}_{2} \mathrm{O}_{3} \\
\text { Liquid: distilled water }\end{array}$ & Chemical & $3: 1$ \\
\hline GIC & $\begin{array}{l}\text { Powder: radiopaque fluoroaluminum silicate } \\
\text { crystals, polycarboxylic acid and pigments; } \\
\text { Liquid: copolymers of polycarboxylic acids, maleic, } \\
\text { itaconic and tartaric acids and purified water }\end{array}$ & Chemical & $1: 1$ \\
\hline
\end{tabular}

GIC: glass ionomer cement (developed at the author's laboratory). MTA: mineral trioxide aggregate. PEGUDMA 400: 400 polietilienoglicoldimethacrylate. TEGDMA: triethyleneglycoldimethacrylate. GDMA-P: glycoldimethacrylatephosphide. UDMA: urethanedimethacrylate. DHEPT-N- N: dihidroxietil-p-toluidine. EDAB: ethyl-4-dimethylamino benzoate. Bis-EMA: dieterdimethacrylate. $\mathrm{Bi}_{2} \mathrm{O}$ : bismuth dioxide. $\mathrm{CaO}$ : calcium oxide. $\mathrm{SiO}_{2}$ : silicon oxide. $\mathrm{Al}_{2} \mathrm{O}_{3}$ : aluminum oxide. 
near neutrality to alkaline throughout the experiment (Fig. 1A).

\section{DTS Test}

Differences in DTS values were observed for the different groups (Fig. 1B). Data from the experimental hybrid group are not shown due to complete solubilization of the material during storage in distilled water for $24 \mathrm{~h}$.

MTA and GIC showed similar values of resistance and the lowest resistance was observed for the experimental paste group $(\mathrm{p}<0.05)$. The experimental resin group exhibited the highest resistance values $(\mathrm{p}<0.05)$.

\section{Cell Viability Assay}

Differences in cell viability for the experimental Hybrid, Paste and Resin groups and MTA, when compared with control group, were observed (values of 93, 90, 86 and 49\% respectively) (Fig. 1C and Table 3). Total loss of cell viability was observed for the GIC group $(\mathrm{p}<0.05)$. While the cell viability for the experimental Paste and Resin groups was significantly lower than that for the control group, the values were still $86 \%$ or greater than those of the control group. For the experimental Hybrid group, cell viability was very similar to that of the control group, not differing significantly. Considerable loss of cell viability was seen for the MTA group (49\% of control), which was significantly different from the other groups (Fig. 1C).

\section{DISCUSSION}

The present study demonstrated that the experimental materials generally had similar or superior properties to those of MTA or GIC, confirming in part the study hypothesis. In this study were evaluated key physical properties ( $\mathrm{pH}$, diametral strength) and biological properties (viability/cytotoxicity), which are fundamental to the initial screening of new materials (7).

MTA showed high $\mathrm{pH}$ values (alkaline) that initially were higher than those obtained for GIC and the experimental cements, except for the experimental Paste group. A high $\mathrm{pH}$ favors the antimicrobial effects of capping cements (13). While the mean $\mathrm{pH}$ values for MTA were similar to those found in another study (13) for the first $24 \mathrm{~h}$, there was a significant decrease over time, which may relate to the specimen size. To evaluate $\mathrm{pH}$ from endodontic materials, circular specimens with dimensions of $10 \mathrm{~mm} \times 1 \mathrm{~mm}$ are often used (13), but different sample dimensions $(1 \times 6 \mathrm{~mm})$ were used in the present study in order to simulate those used clinically as closely as possible.

The initial alkaline $\mathrm{pH}$ of MTA and $\mathrm{CH}$ may be important for growth factor release from dentin, which has been implicated in signaling events for pulp repair (9). After $72 \mathrm{~h}$, the majority of the evaluated materials showed a reduction in $\mathrm{pH}$ values, tending to neutrality, thus indicating an initial release of ions followed by stabilization of the materials. Notably, the experimental resin material showed a stable $\mathrm{pH}$ value throughout the entire observation period, reflecting the higher

Table 2. Mean and standard deviations (SD) of $\mathrm{pH}$ for the different materials stored in culture medium supplemented with fetal bovine serum at the time intervals of $3,24,48$ and $72 \mathrm{~h}$.

\begin{tabular}{cccccc}
\hline Time interval & Paste & Hybrid & Resinous & MTA & GIC \\
\hline $3 \mathrm{~h}$ & $8.50^{\mathrm{AB}}( \pm 0.05)^{\mathrm{ab}}$ & $8.20^{\mathrm{CD}}( \pm 0.14)^{\mathrm{cd}}$ & $8.46^{\mathrm{AB}}( \pm 0.10)^{\mathrm{bc}}$ & $9.52^{\mathrm{A}}(0.16)^{\mathrm{a}}$ & $8.02^{\mathrm{A}}(0.11)^{\mathrm{d}}$ \\
$24 \mathrm{~h}$ & $8.96^{\mathrm{AB}}(0.13)^{\mathrm{ab}}$ & $8.50^{\mathrm{AB}}(0.17)^{\mathrm{c}}$ & $8.65^{\mathrm{AB}}(0.16)^{\mathrm{bc}}$ & $9.26^{\mathrm{AB}}(0.24)^{\mathrm{a}}$ & $8.13^{\mathrm{A}}(0.40)^{\mathrm{c}}$ \\
$48 \mathrm{~h}$ & $8.27^{\mathrm{B}}(0.86)^{\mathrm{bc}}$ & $8.47^{\mathrm{BC}}(0.27)^{\mathrm{bc}}$ & $8.70^{\mathrm{AB}}(0.21)^{\mathrm{ab}}$ & $8.88^{\mathrm{AB}}(0.34)^{\mathrm{a}}$ & $7.94^{\mathrm{A}}(0.68)^{\mathrm{c}}$ \\
$72 \mathrm{~h}$ & $7.50^{\mathrm{BC}}(0.45)^{\mathrm{b}}$ & $7.57^{\mathrm{D}}(0.68)^{\mathrm{b}}$ & $8.89^{\mathrm{BC}}(0.25)^{\mathrm{a}}$ & $7.57^{\mathrm{B}}(0.52)^{\mathrm{b}}$ & $7.38^{\mathrm{B}}(0.43)^{\mathrm{b}}$
\end{tabular}

Different uppercase letters in columns and lowercase letters in rows indicate statistically significant difference $(\mathrm{p}<0.05)$.

Table 3. Mean and standard deviation (SD) for cell viability in the different groups after $24 \mathrm{~h}$ in contact with cement eluates.

\begin{tabular}{lccccc}
\hline Time interval & Paste & Hybrid & Resinous & Control & MTA \\
\hline $24 \mathrm{~h}$ & $2.242(0.180)^{\mathrm{b}}$ & $2.427(0.239)^{\mathrm{ab}}$ & $2.325(0.191)^{\mathrm{b}}$ & $2.598(0.081)^{\mathrm{a}}$ & $1.283(0.158)^{\mathrm{c}}$ \\
\hline
\end{tabular}

Different letters indicate statistically significant difference $(\mathrm{p}<0.05)$. 
dimensional stability of resinous materials (9). This may favor maintenance of the potential antimicrobial effects for longer periods (not tested in the study) and allow a sustained low intensity stimulation of growth factor release from dentin. Furthermore, repair is favored in an alkaline environment (14), especially where acids from cariogenic microorganisms may provide an unfavorable environment for pulp repair (4).

The biocompatibility of dental materials is fundamental to their effectiveness (15). The relatively poor viability seen with MTA compared with the control $(49 \%)$ is suggestive of at least an initial toxic effect of MTA. While some of the previously published studies have reported higher cell viability in the presence of MTA $(16,17)$, the data obtained during the first $24 \mathrm{~h}$ post-setting perhaps reflected the high $\mathrm{pH}$ generated by the material during this period (11). The $\mathrm{pH}$ values for MTA of around 12.0 have been reported in other studies $(18,19)$. The complete loss of viability in the presence of GIC corroborates previous studies (16), highlighting the need for the apposition of another protective material under GICs in deeper cavities. Acid release from GICs during setting represents a possible source of injury to the pulp cells following tubular diffusion and emphasizing the need for a barrier to such diffusion (16). Despite the presence of GIC in the experimental hybrid material, excellent cell viability (93\%) was observed, which may reflect incorporation of the resin component (Bis-EMA 30 ), with its lower diffusion characteristics (10). Good cell viability was also observed with the experimental resin material, which may in part be a consequence of its high dimensional stability and stable $\mathrm{pH}$ post-setting.
The combination of the experimental resin material's stability relative to MTA and the use of a high-molecularweight monomer for its resin component with consequent impact on diffusion behavior (10) highlights the potential biological benefits of this new material.

Determining the resistance of a material is important for its development and subsequent clinical application. The present study evaluated DTS, which is used to test fragile materials with low or no plastic deformation. In this type of test, the specimen is submitted to a compressive load in the diametral plane perpendicular to the longitudinal axis (20). The diametral resistance can be an important parameter for capping materials in cases where a restorative material requiring condensation is placed over the capping material. The low diametral resistance of $\mathrm{CH}$ cement is one of its major limitations, due to the inability to place a condensable restorative material without interposition of another more resistant protective material. In terms of diametral resistance, conventional GIC and MTA showed similar values and the resistance of these materials after setting is sufficient to allow the condensation of restorative materials (21). Nevertheless, the relatively long setting time of both the conventional GIC and the MTA used in this study, represents an important clinical limitation due to the increase of the chair-side time for using either of these materials (22).

In the case of conventional GICs, there is a time delay of at least $8 \mathrm{~min}$ before other restorative procedures can be applied (8), and for MTA the waiting time wait is similar or longer (7). The DTS testing of the experimental hybrid material could not proceed
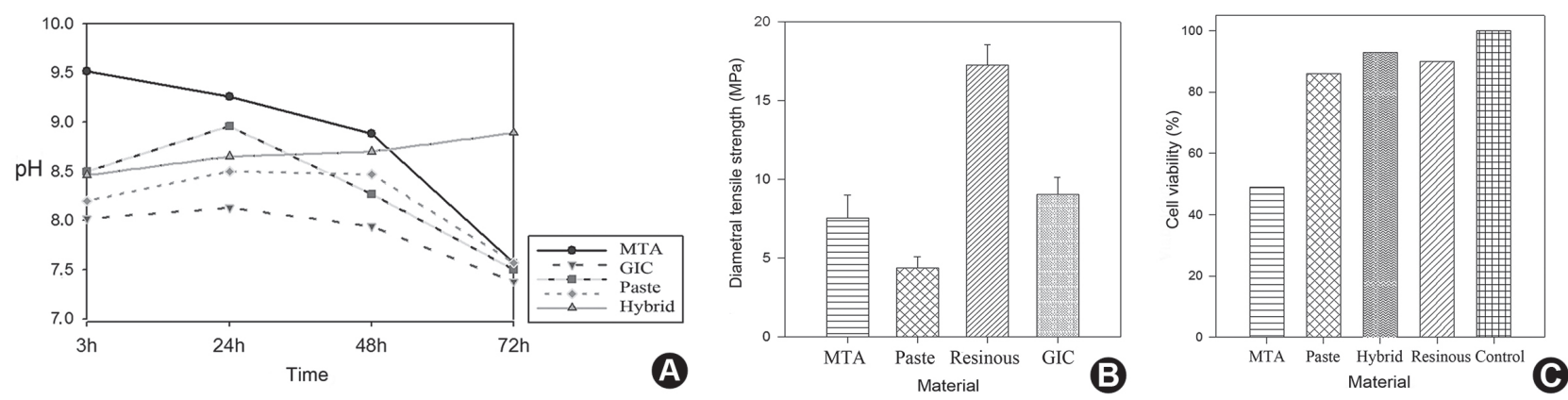

Figure 1. A: Results from $\mathrm{pH}$ values over time, demonstrating that all of them were alkaline with values near to neutrality. There was a decrease in $\mathrm{pH}$ values overtime for all materials, except for the experimental Resinous group. B: Diametral tensile strength of tested cements demonstrating that the highest value observed was related to the experimental Resinous group. The experimental Hybrid group suffered complete dissolution and could not be tested. C: Cell viability after exposure to materials' eluates revealing that MTA produced the highest reduction in absorbance levels, while cell viability values higher than $80 \%$ were observed for the experimental materials. GIC showed total cell depletion and zero value of absorbance readings. 
due to the dissolution of specimens after $24 \mathrm{~h}$ in water. While the material's lack of resistance clearly limits its use clinically, it is interesting to speculate whether the material's dissolution characteristics might have application in the release of bioactive molecules from dentin for novel pulp regenerative therapies (11).

Poor resistance is a limitation for traditional $\mathrm{CH}$ cements (19) and resistance values for the experimental paste material were lower than those from MTA and GIC, suggesting a possible clinical limitation for this material. This contrasts with the experimental Resin group where higher values (17.2 MPa) were obtained compared with all the other groups. The high resistance of this material reflects the inclusion of resin components in its formulation together with the efficiency of light curing. Both the high resistance and curing efficiency are positive characteristics for a pulp capping material ensuring a longer clinical life, especially in the context of the deflections occurring in the material under masticatory load and also reducing the clinical treatment time. In this study, the resinous experimental cement was the material that presented, in general, the best performance among all materials for all conducted tests.

The intention in the present study was to gather positive characteristics of the current materials to develop new cements. Recently, one study questioned the presence of materials/tissues of lower resistance under composite restoration in posterior teeth, because this could contribute to restoration fracture (23). It is also noteworthy that if the capping material obtains its highest mechanical values soon after photoactivation, this material would not suffer the degradation caused by acid conditioning or by application of acidic primers (24). Furthermore, a resinous capping material may have the additional advantage of chemical bonding with the composite resin used for restoration, minimizing the occurrence of failures at the capping material/restorative material interface (25).

In conclusion, on the basis of the analyses conducted in the present study, the experimental MTAbased capping material showed superior performance to the other experimental materials and the currently used commercial materials. Such performance includes the possibility to significantly improving the clinical outcomes obtained with pulp capping materials, but requires further investigation. These results could warrant for the material a potentially better clinical behavior.

\section{RESUMO}

O objetivo deste estudo foi avaliar propriedades físico-químicas e biológicas de novos cimentos experimentais (Híbrido, Pasta e Resinoso) baseado na combinação sinérgica de materiais existentes, incluindo $\mathrm{pH}$, resistência à tração diametral (RTD) e citotoxidade, comparando-os ao MTA (Angelus ${ }^{\circledR}$ ) e a um cimento de ionômero de vidro (CIV) desenvolvido em nosso laboratório. Para a realização dos testes físico-mecânico e biológico, foram confeccionados espécimes com dimensões padrão. O teste de $\mathrm{pH}$ foi realizado por meio de $\mathrm{pH}$-metro digital nos tempos: 3 , 24, 48 e $72 \mathrm{~h}$. Para o teste de RTD, espécimes cilíndricos foram submetidos a carga compressiva até sua fratura. Para avaliação da citotoxidade, utilizou-se o teste MTT. Os dados foram analisados utilizando ANOVA e teste de Tukey $(\alpha=0,05)$. O grupo Pasta apresentou valores de $\mathrm{pH}$ semelhantes ao MTA, assim como o grupo Híbrido seguiu os parâmetros do CIV $(p>0,05)$. Todos os materiais apresentaram valores de $\mathrm{pH}$ alcalinos ou próximos à neutralidade nos tempos avaliados. MTA e CIV apresentaram valores de RTD similares. Os menores e maiores valores observados foram do grupo Pasta e Resinoso, respectivamente $(\mathrm{p}<0,05)$. A viabilidade celular para os grupos MTA, Híbrido, Pasta, Resinoso, quando comparados ao grupo controle foi de: 49, 93, 90 e $86 \%$, respectivamente. O cimento experimental Resinoso apresentou desempenho similar ou superior aos materiais comerciais e experimentais avaliados.

\section{ACKNOWLEDGEMENTS}

The authors are grateful to the Brazilian National Council for Scientific and Technological Development (CNPq) for the research grants to the principal investigator (F.F.D.) (processes \#306187/2009-4; 480466/2009-2; 504921/2010-0; 508440/20106 ) and for the Graduate Fellowship (R.V.F.D.) (process \#551484/2010-1). We gratefully acknowledge the assistance of Dr. A. J. Smith in critically reading this paper.

\section{REFERENCES}

1. Camp J, Fuks A. Pediatric endodontics: endodontic treatment for the primary and young permanent dentition. In: Pathway of the Pulp. Cohen S, Hargreaves K, (Editors). 9th ed. St Louis: Mosby; 2006. p. 822-881.

2. Stanley HR, Pameijer CH. Dentistry's friend: calcium hydroxide Oper Dent 1997;22:1-3.

3. Demarco FF, Tarquinio SB, Jaeger MM, de Araújo VC, Matson E. Pulp response and cytotoxicity evaluation of 2 dentin bonding agents. Quintessence Int 2001;32:211-220.

4. Stanley HR, Swerdlow H, Buonocore MG. Pulp reactions to anterior restorative materials. J Am Dent Assoc 1967;75:132-141.

5. Leites A, Baldissera E, Silva A, Tarquinio S, Botero T, Piva E, et al.. Histologic response and tenascin and fibronectin expression after pulp capping in pig primary teeth with mineral trioxide aggregate or calcium hydroxide. Oper Dent 2011;36:448-456.

6. Aeinehchi M, Eslami B, Ghanbariha M, Saffar AS. Mineral trioxide aggregate (MTA) and calcium hydroxide as pulpcapping agents in human teeth: a preliminary report. Int Endod J 2003;36:225-231.

7. Chan CP, Lan WH, Chang MC, Chen YJ, Lan WC, Chang HH, et al. Effects of TGF-beta $\mathrm{s}$ on the growth, collagen synthesis and 
collagen lattice contraction of human dental pulp fibroblasts in vitro. Arch Oral Biol 2005;50:469-479.

8. Mount GJ. Buonocore Memorial Lecture. Glass-ionomer cements: past, present and future. Oper Dent 1994;19:82-90.

9. Xie D, Brantley WA, Culbertson BM, Wang G. Mechanical properties and microstructures of glass-ionomer cements. Dent Mater 2000;16:129-138.

10. Zanchi $\mathrm{CH}$, Münchow EA, Ogliari FA, Chersoni S, Prati C, Demarco FF, et al. Development of experimental HEMA-free three-step adhesive system. J Dent 2010;38:503-508.

11. Demarco FF, Conde MCM, Cavalcanti BN, Casagrande L, Sakai VT, Nör JE. Dental pulp tissue engineering. Braz Dent J 2011;22:3-13.

12. Tanomaru-Filho M, Faleiros FBC, Saçaki JN, Duarte MAH, Guerreiro-Tanomaru JM. Evaluation of $\mathrm{pH}$ and calcium ion release of root-end filling materials containing calcium hydroxide or mineral trioxide aggregate. J Endod 2009;35:1418-1421.

13. Massi S, Tanomaru-Filho M, Silva GF, Duarte MA, Grizzo LT, Buzalaf MA, et al. $\mathrm{pH}$, calcium ion release, and setting time of an experimental mineral trioxide aggregate-based root canal sealer. J Endod 2011;37:844-846.

14. Elias RV, Demarco FF, Tarquinio SB, Piva E. Pulp responses to the application of a self-etching adhesive in human pulps after controlling bleeding with sodium hypochlorite. Quintessence Int 2007;38:67-77.

15. Modena KC, Casas-Apayco LC, Atta MT, Costa CA, Hebling J, Sipert CR, et al. Cytotoxicity and biocompatibility of direct and indirect pulp capping materials. J Appl Oral Sci 2009; 17:544-554.

16. Damas BA, Wheater MA, Bringas JS, Hoen MM. Cytotoxicity comparison of mineral trioxide aggregates and EndoSequence bioceramic root repair materials. J Endod 2011;37:372-375.
17. Lessa FC, Aranha AM, Hebling J, Costa CA. Cytotoxic effects of White-MTA and MTA-Bio cements on odontoblast-like cells (MDPC-23). Braz Dent J 2010;21:24-31.

18. Bortoluzzi EA, Broon NJ, Duarte MAH, Demarchi ACO, Bramante CM. The use of a setting accelerator and its effect on $\mathrm{pH}$ and calcium ion release of mineral trioxide aggregate and white Portland cement. J Endod 2006;32:1194-1197.

19. Torabinejad M, Watson TF, Ford TRP. Sealing ability of a mineral trioxide aggregate when used as a root end filling material. J Endod 1993;19:591-595.

20. Rodrigues Junior AS, Zanchi CH, Carvalho RV, Demarco FF. Flexural strength and modulus of elasticity of different types of resin-based composites. Braz Oral Res 2007;21:16-21.

21. Brackett WW, Covey DA. Resistance to condensation of 'condensable' resin composites as evaluated by a mechanical test. Oper Dent 2000;25:424-426.

22. Camilleri J, Montesin FE, Silvio LD, Ford TRP. The chemical constitution and biocompatibility of accelerated Portland cement for endodontic use. Int Endod J 2005;38:834-842.

23. Opdam NJ, Bronkhorst EM, Loomans BA, Huysmans MC. 12year survival of composite $v s$. amalgam restorations. J Dent Res 2010;89:1063-1067.

24. Bona AD, Pinzetta C, Rosa V. Effect of acid etching of glass ionomer cement surface on the microleakage of sandwich restorations. J Appl Oral Sci 2007;15:230-234.

25. Ruiz JL, Mitra S. Using cavity liners with direct posterior composite restorations. Compend Contin Educ Dent 2006;27:347351.

Received June 1, 2012

Accepted September 25, 2012 